UDC 37.013 .83

Hanna Dovhopolova

Sumy State Pedagogical University named after A.S. Makarenko ORCID ID 0000-0003-3157-0973

Yana Glyva

Sumy State Pedagogical University named after A.S. Makarenko

ORCID ID 0000-0002-7605-5580

Victoriya Myshakova

Sumy State Pedagogical University named after A.S. Makarenko

ORCID ID 0000-0001-9794-4902

DOI 10.24139/2312-5993/2020.07/064-073

\title{
A NEW PARADIGM OF ADULT EDUCATION IN THE CONTEXT OF FOREIGN LANGUAGE TEACHERS' ADVANCED TRAINING AT A HIGHER EDUCATION INSTITUTION
}

Areas and approaches to professional foreign language teachers' development at higher education institutions are discussed in this article.

Teaching foreign languages requires from teachers not only the methodological and pedagogical competences development, but also constant work aimed at maintaining the required level of foreign language proficiency. Maintaining language competence requires systematic learning of language skills (pronunciation, vocabulary, grammar) and aspects of speech activity (speaking, listening, reading and writing), which puts the teacher in need of interaction with native speakers or those who use the language taught to track new linguistic phenomena.

The directions and opportunities for professional foreign language teachers development in the professional development context at a higher education institution are considered. Advanced training can be carried out in the direction of support of language and speech skills; preparation for the international exam and/or mastering the format of the international exam in order to prepare students for these exams; development of methodological and pedagogical competence; acquaintance with new documents (standards, regulations, rules, etc.) and innovations.

The modern Internet resources which allow to solve various problems for a professional level increase of foreign language teachers are allocated. It should be noted that knowledge of a foreign language opens up opportunities for professionals in various fields. Distinctive features of the adult education format in the context of advanced training at a higher education institution are: openness (access to courses is provided via the Internet); multimedia (video, audio materials and other technological solutions are widely used in the courses); interactivity (active interaction of participants in the educational process with each other through participation in forums and chats); free or conditionally free training (most often the training materials are publicly available, but the receipt of documents is carried out for a fee); leading institutions of higher education are engaged in the development of courses. 
Key words new paradigm, adult education, foreign language teachers' advanced training, institution of higher education.

Introduction. At the beginning of the 21st century, there is a great need for changes in the higher education system, and the importance of higher education for socio-cultural and economic development and building the future, which the younger generation must enter with new skills, knowledge and ideals.

The in-service training system has proven its worth, maintaining relevance over the centuries, as well as its ability to change and stimulate change and progress in society. Due to these rapid changes, society is becoming more knowledge-oriented, so that higher education and research are an important component of cultural and socio-economic development of individuals, societies and nations.

The system of professional development, therefore, must also undergo very significant changes, so that our society, which is currently experiencing a deep crisis of values, has outgrown purely economic interests and turned to deeper dimensions of morality and spirituality.

In Ukraine, against the background of profound social changes, the educational system is in the reform process. The need for reforms is due, in particular, to the fact that in higher education in a number of areas there is a significant gap between the global needs of society and educational outcomes: between the objective requirements of the time and the general lack of education; between professional orientation and the individual's need for harmonious satisfaction of various cognitive interests; between modern methodological approaches to the advanced sciences and the archaic style of their teaching.

Analysis of relevant research. Today in higher pedagogical education and teachers' advanced training there is a search for ways to transition to a new educational paradigm (V. Slastionin, A. Triapitsyna, Z. Vasilieva, E. Bondarevska, A. Orlov, V. Sitarov, N. Sergeiev and others). However, it should be emphasized that it is not reduced to a simple increase in the volume of a number of disciplines or educational terms. We are talking about achieving fundamentally new goals of higher education, which consist in achieving a new level of individual education and society as a whole. Concepts of personality-oriented teacher education (E. Bondarevska, V. Slastionin, etc.), multilevel teacher training (H. Bordovskyi, I. Kolesnikov, L. Sukhorukov, etc.), development of professional and pedagogical and civilization culture (I. Isaiev), the pedagogical profession values (E. Shyianov and others). 
Despite the fact that the number of publications on the implementation of the competence approach in education, a new paradigm of adult education in the context of foreign language teachers' advanced training at a higher education institution, is constantly growing, bringing the deepening of scientific and pedagogical attention to this promising area.

The aim of the article. To find out the essence of a new paradigm of adult education in the context of foreign language teachers' advanced training at a higher education institution. To reveal the content of each indicated components of foreign language teachers' advanced training at a higher education. To identify the new paradigm of adult education in the context of foreign language teachers' advanced training at a higher education institution.

In order to achieve the goal the following research methods have been used: analysis, synthesis, comparison, generalization, concretization, classification, systematization - to study the essence of a new paradigm of adult education in the context of foreign language teachers' advanced training at a higher education institution.

Research results. Attempts to modernize higher pedagogical education and training were already done in the sixties and eighties of the last century. However, they did not lead to serious success because they did not affect the conceptual foundations of the educational system. All this has led to the crystallization of a new educational paradigm in recent years, which is a revision of landmarks and priorities: from pragmatic knowledge to the development of general culture and scientific thinking forms; from the historical context of the scientific knowledge formation to modern ideas about the structure and holistic content of the sciences system (Slastenin, 1991).

The new educational paradigm in Ukraine was formed gradually during the development of the most important directions of higher school reform. Its main elements are set out in the Memorandum of the UNESCO International Symposium "Fundamental (Natural and Humanities) University Education", 1994. As follows from these documents, the new educational paradigm as a priority of higher education considers the focus on the individual's interests, adequate to current trends in social development.

Education in the advanced training system can be considered a direction in the interests of personal development, if it is possible to solve the following tasks:

- harmonize the relationship of man with nature through the development of the modern scientific world picture;

- stimulate intellectual development and thinking enrichment through the modern methods development of scientific knowledge; 
- based on the fact that a person lives in a society, to achieve its successful socialization through immersion in the existing cultural, including man-made and computerized, environment;

- taking into account the integrative trends of science and technology in the higher educational system, including pedagogical, there is a need for a new level of scientific literacy, to create conditions for acquiring a broad basic education, which allows you to quickly switch to related fields.

UNESCO is the only organization in the world currently empowered to develop international projects of a global and regional nature in the fields of education, science, culture and information.

This organization activities are important for forming a holistic international educational space. UNESCO documents defend the rights and opportunities for each individual education, contribute to the formation of regional and national education systems, etc.

The international legal acts of this organization globalize modern education, bringing it to the level of important tasks of educating people in the spirit of peace, democracy, humanism, respect for human rights, preservation of the environment, etc. UNESCO reaffirms the international education importance as an essential part of the economic, social and cultural development of modern society, its comprehensive organization.

Education is the foundation of human rights, democracy, the continuous world development, and therefore education must be available to everyone throughout his or her life. Measures should be taken to ensure coordination and cooperation between general, technical, vocational and higher education, between universities, colleges and technical higher education institutions.

The main terms and concepts that have developed in the international educational community and reflect the accepted view of the structure and functioning of the world educational system. In almost all developed countries there is a system of continuing education. The main missions and goals of professional development, in particular, the mission of continuous society development and improvement as a whole, must be maintained and expanded in order to make it possible:

1) education of highly qualified, responsible citizens, able to meet the needs of society by professional activities, who have adequate training, who are constantly improving their knowledge and skills;

2) free access to higher and continuing education, which provides opportunities for individual development, social mobility. Such education should cultivate citizenship and willingness to take an active part in society on a 
global scale. "Citizens of the world" will protect human rights, promote the constant development of society, democracy to the world;

3) creation, expansion and dissemination of knowledge through research in the scientific, technological, social sphere, in the field of humanities and arts;

4) understanding, preserving, strengthening local, international and historical cultures in the context of cultural pluralism;

5) education development and improvement at all levels, including teacher training.

Ethical role, autonomy, responsibility, forecasting function are considered as one of the traditional functions of world education. According to the recommendations on the status of teachers at higher education institutions proposed at the UNESCO General Conference in November 1997, higher education institutions, staff and students should:

1) maintain and develop their basic functions, adhering to scientific and intellectual ethics in all activities areas;

2) express their own opinion on ethical, cultural and social issues completely independently and with full awareness of their responsibilities, showing the intellectual power necessary for society to realize that the processes taking place in it and to act;

3 ) develop the functions of critical thinking and forecasting through constant analysis of economic, social, cultural and political trends in life; warn about problems and prevent them;

4) protect and actively support the values of peace, justice, freedom and solidarity;

5) maintain full academic autonomy and freedom, presented as rights and responsibilities, at the same time aware of their responsibility to society;

6) help identify factors and trends that contribute to the prosperity of communities, nations and global society.

Strengthening ties with the world of practice and work; analysis and prevention of social needs, as a function of additional education of the XXI century, provides:

1) in societies with a new production paradigm based on knowledge and their application, on the use of information, the connection between further education and the world of practical activities and work must be updated;

2) additional education as a source of professional retraining and advanced training should systematically take into account trends in the world of work, scientific, technological and economic sectors. 
In order for higher education to meet the needs of the labor market, representatives of higher educational systems and practical activities must jointly create curricula that integrate theory and practice (International Society for Third Sector Research). Higher education institutions will also be able to contribute to the creation of new works.

The experience of international teaching plays a very important role, so all higher education institutions should have a special policy for advanced training teachers, which provides training in best practices and methods of teaching and learning about different learning styles, which encourages constant innovation in curricula.

In general, the world community has developed three basic options for public policy on adult education (M onitoring of continuing education, 2006): 1. Adult education is a system of staffing the economy of the state and regions. 2. The degree of state regulation of the system is determined by the program of economic and social development. 3. The demands of the regional labor market, the long-term needs of their development are a guideline for the formation of vocational education policy: the educational system should prepare citizens for professional activity in the context of global challenges of today.

Qualitative assessment, according to UNESCO, includes:

1) definition of "education quality". Quality in higher education is a multifaceted concept that applies to all functions and activities in higher education: academic programs, research and scholarships, faculty, students, knowledge, equipment, community service, and the academic environment. To improve the higher education institution quality requires internal self-esteem and an independent view from the outside, perhaps even foreign experts. Independent national organizations should be established to operate internationally accepted comparative quality standards. Attention should be paid to the specific features of each particular nation, region or education institution to avoid a rigid or one-sided approach to quality assessment;

2) high quality at higher education also implies active work at the international level: knowledge exchange, creation of interactive computer networks, mobility of teachers and students, international research projects. At the same time, national cultural values and peculiarities deserve great attention (Commission of the European Communities. Trans-European M obility Scheme for University Studies (TEM PUS).

New information and communication technologies will continue to change the way knowledge is developed and disseminated. It is also important to note that new technologies offer alternative opportunities to update course content, 
teaching methods, and expand access to further education. However, new information technologies do not reduce the need for teachers, but change their role in the educational process; constant dialogue, which turns information into knowledge and understanding becomes fundamental in this process.

Studies by a number of international research organizations (International Association of Universities, International Association of Educators-Researchers, European Association of Educators-Researchers, International Academy of Sciences, etc.) note that it is necessary to adapt technologies to national, regional and local needs and ensure support and development of technologies. It is necessary to define through international cooperation the goals and interests of all countries (especially developing ones), to help them create equal opportunities for access to new technologies, to strengthen their infrastructure in this area, to promote technology in society. Adhering to the evolution of knowledge of society, ensure high work quality with technology in higher education and equal access for all.

Practically oriented are online platforms for teachers, students and their parents "NaUrok" and "Vseosvita", which presents a series of webinars on the development of foreign language teachers' critical thinking, personal competencies, the use of innovative technologies in the educational process; Internet conferences dedicated to modern educational trends and psychological and pedagogical aspects of teacher work; competitions and Olympiads for foreign language teachers. The intensity of the creation of online platforms and foreign language teachers' advanced training is caused by the reform of the education system in Ukraine:

1) approval of a new Standard of Primary Education, the main idea of which is the focus on the competences acquisition, not just knowledge. Therefore, in the 2018/2019 academic year, all education institutions conduct 354 lessons according to the new Standard, which requires the teacher to acquire new competences and improve the professional level;

2) creation of an inclusive educational environment, which requires foreign language teachers' advanced training who will teach children with special educational needs in inclusive classes of regular schools;

3) motivating the conditions for true teacher autonomy. The updated Law on Education allows for various forms of in-service training - each teacher must study for at least 150 hours over 5 years. Where exactly, he can choose for himself. This will stimulate them to learn new teaching methods and forming critical thinking; 
4) recognition of formal, non-formal and informal education as three main forms. Thus, the state recognizes that such education can exist, and its results can be recognized. However, for this purpose procedures still have to be outlined;

5 ) implementation of the formula $4 \mathrm{~K}$ of the Program of the Educational Alliance "Partnership for Learning in the XXI Century": creativity, critical thinking, cooperation and communication skills.

Conclusions. Adult education is not a priority of state or regional policy. The state fulfills the constitutional guarantees in the field of education and the undertaken obligations. Continuity in education (additional education, advanced training, retraining, etc.) passes to the powers of education institutions and employers. The state adheres to the principle of "neutrality" in relation to the adult education system and does not pay due attention to it. This option is a kind of ensuring the proper functioning of the educational system only in the field of full general and vocational education, advanced training in certain specialties for employees of the public sector in the prescribed manner with appropriate frequency. The state does not require mandatory training for professionals in other areas of the economy, does not fully support additional adult education. Under this option, there is no co-financing of the educational system as a whole, reducing the number of students, reducing the availability of education for vulnerable groups, reducing the scope of non-formal adult education.

International exchange of information and knowledge is a priority for the process of integration of foreign language teachers' advanced training. The principle of solidarity and true partnership between higher education institutions around the world is critical to learning in all areas that contribute to understanding the global society problems, the role of democratic governance and education, the need to unite different cultures and values.

The perspectives of further research are seen in optimal conditions for foreign language teachers' advanced training at higher education institutions in order to promote the teachers' potential.

\section{REFERENCES}

Сластенин, В.А., Шиянов, Е.П. (1991). Гуманизация педагогического образования: теоретическая концепция исследования. Теория и практика высшего образования (Slastenin, V.A., Shyianov, E. P. (1991). Humanization of pedagogical education: theoretical research concept. Theory and practice of higher education, 3, 3-18).

Snyder, T. (Ed.) (1998). Digest of Education Statistics. U.S. Department of Education, National Center for Education Statistics.

Kogan, M., El-Khawas, E., Moses, I. (1994). Staffing Higher Education. Meeting New Challenges, London and Bristol.

Jacobs, G. M, \& Farrell, T. S. C. (2003). Understanding and implementing the CLT (Communicative Language Teaching) paradigm. RELC Journal, 34 (1), 5-30. 
Mollaei, F., Rahnama, H. (2012). Experiential Education Contributing to Language Learning. International Journal of Humanities and Social Science, 2 (21). Retrieved from: http://www.ijhssnet.com/journals/Vol_2_No_21_November_2012/31.pdf

\section{PEЗЮME}

Довгополова Ганна, Глива Яна, Мишакова Вікторія. Нова парадигма освіти дорослих у контексті підвищення кваліфікації викладачів іноземної мови в закладі вищої освіти.

У цій статmі розглядаються напрями та підходи до підвищення кваліфікації викладачів іноземної мови в закладах вищої освіти.

Викладання іноземних мов вимагає від викладачів не лише розвитку методологічних та педагогічних компетентностей, а й постійної роботи, спрямованої на підтримку необхідного рівня володіння іноземною мовою. Підтримання мовної компетентності вимагає систематичного навчання мовним навичкам (вимови, лексики, граматики) та аспектів мовленнєвої діяльності (розмова, аудіювання, читання та письмо), що ставить перед учителем необхідність взаємодіяти з носіями мови або тими, хто використовує мову, яку викладають з метою відстеження нових мовних явищ.

Розглянуто напрями та можливості для підвищення кваліфрікації викладачів іноземної мови в контексті підвищення квалірікації в закладі вищої освіти. Підвищення квалірікації може здійснюватися в таких напрямах: підтримка мовних та мовленнєвих навичок; підготовка до складання міжнародного іспиту та/або засвоєння формату міжнародного іспиту з метою підготовки студентів до цих іспитів; розвиток методичної та педагогічної компетентності; ознайомлення з новими документами (стандартами, положеннями, правилами тощо) та нововведеннями.

Виокремлено сучасні Інтернет-ресурси, які дозволяють вирішувати різноманітні завдання для підвищення професійного рівня викладачів іноземної мови. Слід зазначити, що володіння іноземною мовою відкриває можливості для професіоналів у різних сферах діяльності. Відмінними рисами формату освіти дорослих в контексті підвищення кваліфікації у закладі вищої освіти є відкритість (доступ до курсів здійснюється через Інтернет); мультимедіа (на курсах широко використовуються відео-, аудіоматеріали та інші технологічні рішення); інтерактивність (активна взаємодія учасників освітнього процесу між собою через участь у форумах та чатах); безкоштовне або умовно-безкоштовне навчання (найчастіше навчальні матеріали $\epsilon$ загальнодоступними, але отримання документів здійснюється за окрему плату); розробкою курсів займаються провідні заклади вищої освіти.

Ключові слова: нова парадигма, освіта дорослих, викладачі іноземної мови, підвищення кваліфікації, заклад вищої освіти.

\section{PEЗЮME}

Довгополова Анна, Глива Яна, Мишакова Виктория. Новая парадигма образования взрослых в контексте повышения квалификации преподавателей иностранного языка в учреждении высшего образования.

В этой статье рассматриваются направления и подходы к повышению квалификации преподавателей иностранного языка в учреждениях высшего образования. 
Преподавание иностранных языков требует от преподавателей не только развития методологических и педагогических компетентностей, но и постоянной работы, направленной на поддержание необходимого уровня владения иностранным языком. Поддержание языковой компетентности требует систематического обучения речевым навыкам (произношения, лексики, грамматики) и аспектов речевой деятельности (разговор, аудирование, чтение и письмо), что ставит перед учителем требование взаимодействовать с носителями языка или теми, кто использует язык, который преподают с целью отслеживания новых языковых явлений.

Рассмотрены направления и возможности повышения квалификации преподавателей иностранного языка в контексте повышения квалификации в учреждении высшего образования. Выделены современные Интернет-ресурсы, которые позволяют решать разнообразные задачи для повышения профрессионального уровня преподавателей иностранного языка.

Ключевые слова: новая парадигма, образование взрослых, преподаватели иностранного языка, повышения квалификации, заведение высшего образования.

удк 378.147.091.33-027.22:373.2-051]:37.015.31

Юлія Котелянець Центральноукраїнський державний педагогічний університет імені Володимира Винниченка ORCID ID 0000-0003-3932-1824 DOI 10.24139/2312-5993/2020.07/073-085

\section{ФОРМИ Й МЕТОДИ ПРОФЕСІЙНОЇ ПІДГОТОВКИ МАЙБУТНІХ ВИХОВАТЕЛІВ ДО ФОРМУВАННЯ ТВОРЧОСТІ ДІТЕЙ СТАРШОГО ДОШКІЛЬНОГО ВІКУ ЗАСОБАМИ ІНТЕГРАЦІЇ МОВЛЕННЄВОЇ ТА КОНСТРУКТИВНОЇ ДІЯЛЬНОСТІ}

Майбутній вихователь як суб'єкт педагогічної творчості повинен бути сам срормований як творча індивідуальність. Забезпечення міждисциплінарних зав'язків між дисциплінами різних циклів у процесі підготовки майбутніх вихователів до формування творчості дітей старшого дошкільного віку дозволяє сформувати в майбутніх вихователів уміння інтегрувати знання з дисциплін. Творчому опануванню педагогічної діяльності сприяли дискусії, диспути під час обговорення результатів виконання творчих завдань, онлайн тренінгів. Реалізація інтерактивного підходу в підготовці майбутніх вихователів відбувається на основі організації інтерактивного навчання.

Ключові слова: майбутній вихователь, професійна підготовка, творчість, дистанційна освіта, тренінг, дискусія, творчі завдання, інтерактивний підхід.

Постановка проблеми. В умовах євроінтеграції наукового простору та модернізації системи вищої педагогічної освіти відбуваються зміни у процесі професійної підготовки майбутніх фахівців дошкільної освіти. Завдання 